\title{
İslâm Hukukundaki Hidâne Müessesesinin Günümüz Uygulaması ile Mukayesesi*
}

\author{
A Comparison of the Hidanah Tradition in Islamic \\ Law with Current Practice
}

Canan Tatar**

$\ddot{O} z \bullet$ Toplumun temel yapı taşını aile oluşturmaktadır. Bu sebeple aslolan ailenin birlik, beraberlik içerisinde ve huzurlu bir ortamda çocuklarını yetiştirebilmesidir. Evlilik birliği devam ettiği müddetçe eşler, çocuklarının bakımını ve onlarla ilgili sorumlulukları birlikte yerine getirmektedir. Ancak boşanma ya da başka sebeplerden dolayı bu her zaman mümkün olamamaktadır. Boşanma halinde çocukların kimin yanında kalacağı, bakım ve yetiştirilme sorumluluğunun kime ait olacağı meselesi gündeme gelmektedir. Bu süreç bazı durumlarda özellikle çocukları olumsuz şekilde etkilemektedir. Bu olumsuz etkinin giderilmesi amacıyla gerek İslâm hukukunda gerekse modern hukukta boşanmış ailelerin çocuklarına yönelik hukukî düzenlemeler yapılmıştır. Biz bu çalışmamızda, İslâm hukukundaki hidâne ve velâyet kavramının tanımı, mahiyeti ve kapsamı üzerinde kısaca durduktan sonra günümüz hukukundaki boşanmaların sonucunda velâyet ile ilgili düzenlemeleri ve her iki hukuk arasındaki farklılıkları ortaya koymaya çalışacağız.

Anahtar Kelimeler: İslâm, Boşanma, Çocuk, Hidâne, Velâyet.

-...............

* İstanbul Ticaret Üniversitesi Kadın ve Aile Uygulama ve Araştırma Merkezi ile Kadın ve Demokrasi Derneği (KADEM) ortaklığında, 8 Mart 2018 tarihinde düzenlenen "4. Toplumsal Cinsiyet Adaleti: Boşanma" kongresinde sunulan bu makale, daha önce hazırlanmış olan "İslam'da Boşanmanın Çocuklar Üzerindeki Hukuki Sonuçları” isimli yüksek lisans tezinden üretilmiştir.

** İstanbul Üniversitesi Sosyal Bilimler Enstitüsü Temel İslam Bilimleri İslam Hukuku ABD Doktora Adayl. e.mail: canan_tatar1430@hotmail.com. Orcid ID: 0000-0002-7493-7037.

\footnotetext{
Başvuru: 7 Nisan 2018

Kabul: 10 Haziran 2018

DOI: $10.21798 /$ kadem.2018141983
}

Copyright (c) 2018 • KADEM Kadın ve Demokrasi Derneği

kadinarastirmalari.kadem.org.tr

ISSN 2149-6374 • Haziran 2018 • 4 (1) • 77 - 102 


\begin{abstract}
Family is the basic unit of society. Bringing up children in a peaceful environment within the family is essential. This, however, does not always happen. In today's society, we witness the increase in the number of divorced families, which ends with various problems. In cases of divorce, the question "who will hold the right and responsibility of childcare" arises. In order to eliminate the negative effects caused by divorce, we must provide the best possible environment for children, and both parents - for both the parent who the child will/will not stay with and - must fulfill their duties towards the child.

Both Islamic and Modern law established regulations which prevent the children of divorced families from being affected by those unfavorable conditions. This study firstly discusses the scope of traditional concepts like "hidanah" and parental custody related to childcare and how these issues were handled by Islamic Law, which is later compared to modern law.
\end{abstract}

Keywords: Islam, Divorce, Child, Hidanah, Custody.

\title{
Giriş
}

Günümüzde boşanmanın giderek artması birçok sorunu da beraberinde getirmektedir. Boşanma sonrasında oluşan şartlar gereği anne ve babaları ile birlikte yaşama hakları ellerinden alınan çocuklar bir açıdan yetim kalmaktadır. Çocukların her hâlükârda taraflardan birisiyle yaşama zorunluluğu onları hem sosyal hem de psikolojik açıdan olumsuz bir şekilde etkilemektedir. Bu durum çocukların sağlıklı ve faydalı bireyler olarak topluma katılmalarına engel olabilmektedir. Bu olumsuzlukların giderilebilmesi için çocukların iyi şekilde yetişmelerine imkân sağlayacak ortamların hazırlanması ve gerek çocuğun yanında kalacağı tarafın gerekse diğer tarafın üzerine düşen sorumlulukları hakkıyla yerine getirmesi gerekmektedir. Aksi takdirde hem Kur'ân-ı Kerim'de hem de Sünnet'te çocuğun korunması ve yetiştirilmesi hususunda anne ve babalara yüklenen sorumluklar yerine getirilmemiş, makâsıd-ı hamseden biri olan neslin korunması prensibine riayet edilmemiş olur.

İslâm hukukunda doğduğu andan itibaren çocukların velâyet hakları babalarında kalmakla birlikte evlilik birliği devam ettiği süre içerisinde anne ve babalar çocuklarını yetiştirme konusunda 
eşit haklara sahiptir. Fakat evlilik birliğinin sona erip boşanmanın gerçekleşmesi durumunda, anne ve babaların çocukları üzerindeki hak-yetki ve sorumlulukları da müssterek olarak devam etmekle beraber şartlar gereği bölünmektedir. Böyle bir durumda çocuğun kimin yanında ne kadar süre ile kalacağı, çocuk üzerinde kimin hangi hak ve yetkilere sahip olduğu ve bu yetkileri hangi oranda kullanabileceği gibi sorunlar ortaya çıkmaktadır. Velâyet hakkının babada olması, boşanma sonucunda da aynı şekilde devam edeceği anlamına mı gelir? Yoksa annenin de velâyet hakkı var mıdır? Daha doğrusu boşanmayla birlikte çocuğun bakım ve ihtiyaçları gerek maddî gerekse manevî açıdan kim tarafından karşılanmalıdır? Bunun şartları nelerdir? Ne kadar süre ile sınırlıdır? Ve bütün bunlar neye göre tespit edilir? şeklinde cevaplanmayı bekleyen birçok soru akla gelmektedir.

Tüm bu sorular İslâm hukukunda velâyetin bir alt türü olarak kabul edilen hidâne kavramını gündeme getirmektedir. Modern hukukta ise boşanmadan sonra çocukların hukukî durumu Medenî Kanunun 182 ve 183. maddelerinde düzenlenmekte ve velâyet kapsamında ele alınmaktadır.

\section{Kavramsal Çerçeve}

Boşanma sonrasında çocukların kimin yanında kalacağı meselesi İslâm hukuku ve günümüz hukukunda birbiriyle bağlantılı olan farklı kavramlar açısından ele alınmaktadır. Bu nedenle öncelikle burada hidâne, velâyet ve vesâyet kavramlarının tanımları ve mahiyetleri üzerinde durulacaktır.

\section{A. Çocuğun Bakım ve Sorumluluğu ile İlgili Kavramlar}

\section{Hidâne Kavramı}

Arapça "h.d.n" (حض-ضان) kökünden türeyen hidânelimesi mastardır (Fîrûzâbâdî, 1987, C: IV, s. 215). Sözlükte, kuşun yumurtasını kanadının altına alıp sînesine basması anlamından yola çıkılarak kadının çocuğunu kucağına alıp bağrına basmasina (Ezherî, "t.y.” C: IV, s. 209; Feyyûmî, "t.y.” C: I, s. 69), onu 
korumasına (İbn Fâris, 1980, C:II, s.73; İbn Manzûr, 2008, C: IV, s. 152; Zebîdî, 1994, C: XVIII, s.153) ve terbiye etmesine (Cevherî, 1990, C: V, s. 2102) hidâne denilmiştir.

Terim olarak ise hidâne, bu hakka sahip olan kimsenin çocuğu ve kendi işlerinde bağımsız olmayan kimseleri himaye altına alması, terbiye etmesi ve onları zararlı şeylerden korumasıdır (İbn Âbîdin, 2000, C: XIX, s. 429).

\section{Velâyet Kavramı}

Velâyet kelimesi, "v.l.y."(ولي) fiilinin mastarıdır. Sözlükte; yardım etmek, birisinin işini üzerine almak, yakın olmak (Ezherî, "t.y.", C: XV, s. 447; İbn Fâris, 1980. C: II, s.141), idare etmek, düzenlemek (Cevherî, 1990, C: VI, s. 2528) ve dost olmak (İsfehânî, 2009, s. 885) anlamlarına gelmektedir. Aynı kökten türeyen el-velîyyü (الولي) kelimesi de, velî (İbn Manzûr, 2008 C:XV, s. 281; Fîrûzâbâdî, 1987 C: IV, s. 401), vasî, neseb bakımından yakın olan (Feyyûmî, "t.y." C:II, s. 157), yetimin işlerini yürüten (Zebîdî, 1994, C: XX, s. 312) ve kadının nikâh akdini yapan kimse (Ezherî, “t.y.”, C: XV, s. 449) anlamlarında kullanılmaktadır.

Velâyet terim olarak genelde iki şekilde tanımlanmıştır. Bunlardan biri, karşı tarafın rıza ya da onayına bakılmaksızın sözün bir başkasında geçerli kılınması (Cürcânî, 1983, s. 254; Elmalılı, 1997, C: V, s. 425) diğeri reşid bir kimsenin ehliyeti noksan olan birisinin şahsî ve malî işlerini yürütme konusunda yetki sahibi olmasıdır (Serahsî, h.1324., C: IV, s. 213).

Günümüz modern hukukunda ise velâyet, genellikle "kural olarak küçüklerin, istisnaî hallerde ise kısıtlı kimselerin bakım ve korunmalarının sağlanması amacıyla onların şahısları ve malları üzerinde anne babanın sahip olduğu görev, yetki ve hakların tümü” şeklinde tanımlanmıştır (Oğuzman ve Dural, 1998, s. 272).

\section{Vesâyet Kavramı}

Vesâyet sözlükte, vasî tayin etmek, birine vasiyet etmek ve bir şey vermek (Cevherî, 1990, C: VI, s. 2525; Fîrûzâbâdî, 1987, C: IV, 
s. 400), öğüt vermek, tavsiye etmek, (İsfehânî, 2009, s. 873; Zebîdî, 1994, C:XX, s. 295) ve vasiyeti kabul etmek (Feyyûmî, “t.y.”, C: II, s. 90) anlamlarına gelmektedir.

Terim olarak bir kimseye çocuklarıyla ilgili işlerinde ve mallarında tasarrufta bulunmak üzere yetki verilmesidir. Vesâyet yetkisinin verildiği kimseye vasî denilmektedir. Daha açık bir ifadeyle vasî, velâyet altında bulunmayan küçük veya ehliyeti kısıtlı olan kimselerin menfaatlerini korumak için sulh mahkemesi tarafından tayin edilen kanunî temsilcidir (Erdoğan, 2010, s. 598).

Günümüz hukukunda ise vesâyet, küçük ve kısıtlı kimselerin, şahıslarını korumak ve mallarını idare etmek demektir (Ergüney, 1973, s. 492). Aslında reşid olmayan bu çocuklar veya kısıtlı olan bu kimseler, kural olarak velâyet altında bulunurlar. Fakat anne babanın ölmesi veya velâyet görevini yerine getir(e)memesi gibi durumlarda Medenî Kanun vesâyet kurumunu öngörmüştür (Oğuzman ve Dural, 1998, s.425).

\section{B. Kavramlar Arası İlişki}

İslâm hukukunda velâyet, şahıs üzerinde velâyet (el- velâyet ale'n- nefs) ve mal üzerinde velâyet (el- velâyet ale'l- mal) olmak üzere iki kısma ayrılmaktadır. Bunlardan birincisi, çocuğun bakım, gözetim ve terbiyesi ile birlikte şahsına bağlı olan haklarının kullanımına ve tasarrufuna yönelik velâyet, ikincisi ise çocuğun mallarının korunmasına ve idaresine yönelik velâyettir. Bu hakka sahip olan kimse (velî), temsil ettiği kimsenin, evlenme ve boşanma gibi şahsî işlerini de yürütmektedir. Şahsa yönelik velâyette çocuğun bakım, gözetim ve terbiyesi ile ilgili velâyet, hidâne olarak isimlendirilir (Tantâvî, 1979, s. 406; Abdülazîz Musa Amir, "t.y.”, s. 204; Celal Erbay, 1998, s. 163, Şükrü Özen, "Velâyet”, DİA, C: XXXXIII, s. 16, Ali Bardakoğlu, "Hidâne", DİA, C: XVII, s. 467). Vesâyet sahibi kimse (vasî) ise, temsil ettiği kimsenin sadece malî ve hukukî işlerini yürütmektedir. Görüldüğü üzere bunların içerisindeki en üst kavram velâyettir. Bu sebeple gerek hidâne gerekse vesâyet, velâyetin bir alt türü olarak kabul edilmektedir (Hayrettin Karaman, 2005, s. 280; Ali Bardakoğlu, "Vesâyet", DİA, C: XXXXIII, s. 66). 


\section{Hidâne Müessesesi}

İslâm hukukuna özgü olan hidâne müessesesinin temeli $\mathrm{Hz}$. Peygamber dönemine kadar dayanmaktadır. Ailelerin çocukları ile ilgili problemleri Hz. Peygamber'e iletmeleri, özellikle boşanma sonrasında çocukların kimin yanında kalması gerektiğine yönelik sordukları sorular ve Hz. Peygamber'in bu durumda olan kimselere verdiği cevaplar bu uygulamanın ilk örneklerini teşkil etmektedir. Konunun özünü oluşturan ilgili rivayetlerden birkaçı şöyledir:

Hz. Peygamber bir rivayette (s.a.v) "Her kim anne ile çocuğunun arasını ayırırsa, Allah klyamet gününde onunla sevdiklerinin arasını ayırır" (Ahmed b. Hanbel, C:XXXVIII, 486, 496; İbn Mâce, 1996, C: III, s. 60, Ticaret, 46; Tirmizî, Buyû, 52) buyurmuştur.

Abdullah İbn Amr'dan nakledilen bir rivayette; bir kadın gelerek: "Ya Resûlullah, ben şu oğlumu karnımda taşıdım, göğsümden emzirdim, kucağımda korudum. Şimdi babası beni boşadı ve bunu elimden almak istiyor" der. Hz. Peygamber de "Evlenmediğin müddetçe sen daha hak sahibisin" cevabını verir (Ebû Dâvûd, 1998, Talak, 35).

Bu ve benzeri rivayetlerde, anne köle dahi olsa özellikle çocuğun annesine ihtiyaç duyduğu bir dönemde, onların birbirlerinden ayrılmamaları gerektiği sonucu çıkarılmıştır. Nitekim Hz. Ebû Bekir, Hz. Ömer'in (r.a) boşamış olduğu karısından doğan oğlu Asım için: "Annesi evlenmediği müddetçe oğluna daha layıktır. Zira o(anne), daha şefkatli, daha lûtufkâr, daha merhametli, çocuğa daha düşkün ve re'fet sahibidir" (Ahmed b. Hanbel, XI, 310-311; Ebû Dâvûd, Talak, 35) demiştir.

Rivayetlerde geçen "ehak" (daha hak sahibi) ifadesi, eşlerin boşanması durumunda çocuk üzerinde annenin mi yoksa babanın $\mathrm{m}$ daha fazla hak sahibi olduğu noktasında önemli delillerden biri olarak zikredilmektedir. Burada özellikle üzerinde durulan konu, çocuğun bakım ve yetiştirilmesinden kimin sorumlu olacağı ya da bu hakka kimin sahip olacağı meselesidir. Rivayetlerde tartışmanın odak noktasını "daha hak sahibi" ifadesi oluşturmaktadır. Fakat bu ifade anne için "bir başkası ile evlenmediği müddetçe" 
şeklinde kayıtlanmıştır. Bu sebeple fikıhta annenin yabancı birisi ile evlendikten sonra da bu hakka sahip olup-ol(a)mayacağı meselesi tartışılmıştır.

Mezheplerin yaklaşımlarında farklılıklar bulunmakla birlikte annenin yabancı biriyle evlenmesi durumunda çocukla ilgili olarak temelde iki görüş bulunmaktadır: Bunlardan birincisi evlilikle annenin çocuğunu yanına alma hakkını kaybetmeyeceği görüşü ikincisi ise evlendiği takdirde bu hakkı kaybedeceği görüşüdür.

Annenin yabancı biriyle evlenmesi durumunda hiçbir şekilde bu hakkı kaybetmeyeceği görüşüne sahip olanlar, evlenilmesi haram olan kadınlarla ilgili hükümlere işaret eden Nisâ sûresinin 23. âyetini annenin evli dahi olsa çocuğunu yanına alma hakkına sahip olduğunun göstergesi olarak zikretmişlerdir. Nitekim âyette “...Kendileriyle zifafa girdiğiniz karllarınızdan olup evlerinizde bulunan üvey kızlarınız da size haram kılındı...” buyrulmaktadır. Onlara göre eğer evlilik bu hakkı kaybettirseydi âyette geçen (وَرَبَائبْكُمُ), “üvey kızlarınız" ifadesi kullanılmazdı. Yine anne ve babaların çocukları üzerindeki sorumluluklara temas eden ve süt emzirme hakkının anneye ait olduğunu bildiren Bakara sûresinin 233. âyetini ikinci bir delil olarak getirmişler ve anne evlenmiş dahi olsa bu hakkın başka birine geçebileceğine yönelik bir nas bulunmadığını ifade etmişlerdir. Ayrica Hasan Basri ve İbn Hazm da Ümmü Seleme'nin Hz. Peygamber'le evlendiğinde kızı Zeynep’i yanında getirmiş olması, Hz. Enes'in başka biriyle evli olan annesinin himayesinde kalması ve Hz. Hamza'nın kızının Hz. Câfer'le evli olduğu halde teyzesinin himayesine verilmesi gerekçesiyle annenin evliliğinin bu hakka engel olmadiğı görüşüne sahiptir (İbn Hazm, 2001, C: XI, s. 745; Ahmed Abdulhay, “t.y.", s. 44-45; Sultan Aksakal, 2003, s. 177).

Annenin çocuğunu yanına alma hakkını kaybedeceği görüşüne sahip olanlar ise, annenin öncelikli olarak hak sahibi olduğunun delili olarak getirilen Abdullah b. Amr rivayetini esas almışlardır. Rivayette Hz. Peygamber'in (انت أحق) "sen daha hak sahibisin” ifadesini (ما لم تنكحى) "evlenmediğin müddetçe” şeklinde kayıtlamasından hareketle, bu ifadenin mutlak olarak annenin evlenmesi durumunda hakkını kaybedeceği şeklinde yorumlamışlardır (Şîrbînî, 1997, C: 
III, s. 592; Ahmed Abdulhay, "t.y.", s. 44-45). İlgili rivayet bir taraftan annenin çocuğunu alma konusunda öncelikli olarak hak sahibi olduğuna işaret ederken diğer taraftan "evlenmediğin müddetçe" ifadesi ile hakkın kapsamını daraltmaktadır. Aynı şekilde Hz. Ömer'in oğlu Asım'ı annesinden almak için verdiği mücadelede Hz. Ebû Bekir, annenin evlenmediği müddetçe çocuğu alma konusunda daha hak sahibi olduğunu belirterek çocuğu annesine teslim etmiştir. Her iki rivayette de nikâh ifadesi geçmektedir. Burada nikâh ifadesini mutlak olarak alan fakihlerden bir kısmı evlilik akdinin yapılması durumunda annenin hakkını kaybedeceği görüşüne sahip olmuştur (Serahsî, h.1324, C: V, s. 210; Ensârî, 2001, C: VII, s. 505-506; İbn Kudâme, 1998, C: XI, s. 420). Mâlikîler ise annenin evlenmesinin bu hakkı doğrudan düşürmeyeceğini ancak çocuğun bazı şartlarla anneden alınabileceğini belirtmişler ve bunun için evlilikle birlikte zifafın gerçekleşmiş olmasını şart koşmuşlardır (Derdîr, 1986, C: II, s. 759; Zeki Süleyman, 2013, C: XVI, No: 59, s. 80).

Evliliğin annenin çocuğunu yanına alma hakkına engel olduğu görüşünü savunanlara göre, evlendiği kişinin kadının üzerinde hakkı vardır. Eşiyle ilgilenmek zorunda olan annenin çocuğunun ihtiyaçlarını tam olarak karşılamayacağı belirtilmiştir. Ayrıca üvey baba çocuğa kötü muamelelerde bulunarak çocuğun zarar görmesine de sebep olabilir. Bu ise çocuğun annesine teslim edilmesindeki amaca aykırıdır ve böyle bir durumda çocuğun zarar görmesi söz konusu olur (Derdîr, 1986, C: II, s. 759). Çocuğun menfaatine zarar veren bu durumlar sebebiyle fakihlerin bir kısmı, annenin bu hakka sahip olamayacağını ve babanın böyle bir evliliğe rıza göstermediğinde çocuğu annesinden alabileceğini belirtmişlerdir (Serahsî, $h$. 1324, C: V, s. 210).

Görüldüğü üzere fikıhta bu mesele daha çok annenin evlenmesi ile ilişkili olarak tartışılmıştır. Ancak çocuk açısından annenin ya da babanın evlenmesi arasında bir fark olmadığı belirtilmiştir. Hatta üvey babanın bazen üvey anneden daha şefkatli ve merhametli olabileceği ve böyle bir durumda çocuğun üvey annesine oranla üvey babasından daha az zarar görmesinin muhtemel olduğunu ifade edenler de olmuştur (İbn Âbidîn, 2000, C: X, s. 458; Ahmed Abdulhay, "t.y.", s. 44-45). 
Daha önce de belirtildiği gibi fakihlerin bir kısmına göre, annenin evlenmesi onun çocuğuna bakıp yetiştirme hakkına engel durumlardan biridir. Nitekim anneye ihtiyacı olduğu bir dönemde çocuğun ondan alınması sonucunda ona bakacak başka birine teslim edilmesi gerekmektedir. Bu sebeple fikıhta anneden sonra bu hakka kimin sahip olacağı meselesi tartışılmış ve konuyla ilgili farklı görüşler ileri sürülmüştür.

Annenin bulunmadığı ya da herhangi bir sebeple bu hakka sahip olamadığı durumlarda anneden sonra hakkın kime ait olacağı konusu da "daha hak sahibi” ifadesi ile ilişkilendirilmiştir. Hz. Hamza'nın yetim kalan kızıyla ilgili rivayette konu daha net anlaşılmaktadır.

Resûlullah (s.a.v)'in huzurunda, "Ali, Câfer ve Zeyd b. Hârise, Hz. Hamza'nın yetim kalan kızının kimin himayesinde bulunacă̆ konusunda davalaşmışlar. Hz. Ali; 'Ben onu almaya herkesten daha hak sahibiyim, çünkü amcamın kızıdır' demiş. Hz. Zeyd; 'O benim kardeşimin kızıdır' iddiasında bulunmuş, Hz. Câfer de; 'Bu kız benim amcamın kızıdır, teyzesi de nikâhımdadır' şeklinde beyanatta bulununca, Hz. Peygamber (s.a.v) kızı teyzesinin kocası olan Hz. Câfer'e vermiş ve 'Teyze, anne konumundadır' buyurmuştur. Ali'ye, 'Sen benden, ben de sendenim', Câfer'e 'Benim hilkat ve ahlâkıma benzedin', Zeyd'e ise sen 'Bizim kardeşimiz ve mevlamizsın' buyurarak” hepsinin ayrı ayrı gönüllerini almıştır (Ebû Dâvûd, Talak, 35; Tirmizî, Birr, 6).

Görüldüğü üzere bu rivayette Hz. Hamza'nın kızı teyzesi sebebiyle Hz. Câfer'e verilmiştir. Burada annenin "daha hak sahibi" olması ifadesi ile kendisinden sonra bu hakkın öncelikli olarak anne tarafına mı yoksa baba tarafına mı ait olduğu konusu gündeme gelmektedir. Bu sebeple, anneden sonra teyze ya da babaanneden hangisinin öncelikli olarak hak sahibi olduğu konusu üzerinde durulmuştur.

Konuyla ilgili ele alınan meselelerden biri de, çocuğun belirli bir yaşa geldikten sonra anne ya da babası arasında seçim hakkına sahip olup olmadığıdır. 
Ebû Hüreyre (r.a)'dan rivayet olunduğuna göre bir kadın gelerek "Ya Resûlullah, gerçekten kocam oğlumu götürmek istiyor. Hâlbuki oğlumun bana faydası dokunmaya başladı. Bana i‘nabe kuyusundan su taşımaya başladı." Arkasından kocası geldi ve bunun üzerine Peygamber (s.a.v): "Ey çocuk! Şu baban, şu da annen! (haydi, bakalım) hangisini istersen onun elinden tut, demiş, çocuk hemen annesinin eline yapışmış, annesi de onu alıp götürmüştür"(Tirmizî, Ahkâm, 21; İbn Mâce, Ahkâm, 22).

Rivayetten de anlaşılacağı gibi, burada çocuğun belirli bir yaşa gelmesinin ona anne ya da babasının yanında kalmak için bir seçimde bulunma hakkı tanıyıp tanımayacağı meselesi tartışmanın özünü oluşturmaktadır. Şâfiî mezhebinde temyiz döneminden sonra kız erkek çocuk ayrımı yapılmaksızın çocuk, anne ve babasından birisini seçme hakkına sahiptir. Hanbelî mezhebinde ise seçim hakkı sadece erkek çocuk için tanınmıştır (Mâverdî, 1994, XI, s. 499; İbn Kudâme, 1997, XI, s. 415).

Konuyla ilgili delil olarak gösterilen son rivayet ise şu şekildedir:

Râfi b. Sinan'dan rivayet olunduğuna göre, kendisi müslüman olmuş, karısı ise müslüman olmayı kabul etmemiştir. Bunun üzerine Hz. Peygamber (s.a.v) anneyi bir tarafa babayı da bir tarafa almıs, çocuğu da aralarına oturtmuştur. Derken çocuk annesine yönelmiş, Resûlallah (s.a.v): "Ya Rab, buna hidayet ver diyerek dua etmiş. Bu sefer çocuk hemen babasına yönelmiş, babası da onu almıştır” (Ebû Dâvûd, Talak, 26; Nesâî, Talak, 52).

$\mathrm{Bu}$ rivayet de fikhın ilgili bölümünde anne babanın dindarlığına ilişkin konularda delil olarak ele alınmış ve tarafların müslüman olma şartını taşıyıp-taşımaması üzerinde durulmuştur. Hanefî̀ ve Mâlikî âlimlerden bir kısmına göre çocuğa dinî açıdan zarar vermemesi kaydıyla ister erkek ister kadın olsun çocuğun yanında kalacağı tarafta müslüman olma şartı aranmaz (Desûkî, 2003, C: III, s. 512; İbn Nüceym, 1997, C:IV, s. 282; Ahmed Abdulhay, “t.y.”, s. 35). Bazı fakihlere göre ise çocuk, müslüman olmayan annenin yanında dinler arasındaki farkı idrak edebilecek bir duruma gelinceye kadar kalabilir. Ancak kişinin çocuğa kendi diniyle ilgili ritüelleri aşılama 
tehlikesini göz önünde bulunduran bir kısım Hanefî fakih, çocuğun bu durumu fark etmesini temyiz dönemine ulaştığı yedi yaşla sınırlandırırken Zâhirîler ise çocuğun böyle bir kimsenin yanında kalacağı sürenin en fazla sütten kesileceği döneme kadar olabileceğini savunmuştur (İbn Hazm, 1970, C: X, s. 742; İbn Âbidîn, 2000, X, s. 431; Zekiyyüddin Şa'ban, 1989, s. 624).

Özetle, ilgili rivayetlerde; ya anne ile baba çocuğuyla ilgili hükümleri sormakta ya da bu tartışma baba ile anneanne arasında geçmektedir. Bazen taraf olarak babanın ya da annenin bulunmadığı tartışmalarda söz konusudur. Rivayetlerde görüldüğü üzere $\mathrm{Hz}$. Peygamber'e sorulan sorulardan tartışmanın taraflarının genellikle değiştiği görülmektedir. Bu sebeple rivayetlere konu olan meselelerde çocuk üzerinde hak iddia eden tarafın kim olduğu ve tartışmanın kimler arasında gerçekleştiği konusu, hükümlerin belirlenmesi açısindan önem arz etmektedir.

Klasik fıkıh literatüründe çocuğun bakım ve yetiştirilmesinden sorumlu olan kişinin hangi şartlarla ve ne kadar süre ile bu hakka sahip olacağı ile bunların belirlenmesi hususundaki düzenlemeler genellikle ilgili rivayetler doğrultusunda talak (boşanma), nafaka, velâyet vb. konuların altında bir bölüm olarak hidâne çerçevesinde ele alınmıştır.

Boşanmanın doğal sonucu olarak çocukların bakıma muhtaç oldukları dönemde anne ya da babasından birisinin yanında kalması gerekmektedir. Çocuğun en iyi şekilde yetiştirilebilmesi için ondan sorumlu olan tarafın taşıması gereken bazı şartlar bulunmaktadır ve bunlar çocuğun maslahatı dikkate alınarak belirlenmiştir. Kişinin çocuğu yanına alabilmek için taşıması gereken ortak şartlar kapsamında kabul edilen akıl, hürriyet, güç ve kudret sahibi olmak vb. şartlar hemen hemen tüm mezheplerde kabul edilmiştir. Fakat bazı şartlara ilişkin görüşlerde az da olsa farklılıklar bulunmaktadır (Derdîr, 1986, C: II, 761; Abdullah Çolak, 2017, s. 309). Özellikle birbiriyle bağlantılı olan ahlâkî açıdan güvenilirlik (fâsıklık) ve müslüman olma şartı kişinin kadın veya erkek olması ve çocuğun bu hakka sahip olan kimsenin yanında kalacağı süre açısından farklı değerlendirilmiştir. Sonuç itibariyle, tüm şartlarda öncelikle 
çocuğun menfaati göz önünde bulundurulmuş ve temel gaye onun zarar görmemesi olmuştur.

Yine farklı görüşler olmakla birlikte fakihlerin bir kısmı yukarıda bahsedilen şartların yanı sıra-ilgili rivayetlerden hareketle-özellikle bir başkasıyla evlenmeme şartını sadece annenin sahip olması gereken bir şart olarak zikretmiştir. Sadece babanın sahip olması gereken şart ise çocuğun bakıma ihtiyacı olduğu dönemde yanında ona bakabilecek yetkinliğe sahip eşi, annesi ya da teyzesi gibi bir kadının bulunmasıdır.

Eşlerin boşanma sonrasında bakım ve yetiştirme konularında yukarıda verilen genel şartlara eşit derecede sahip olması ve her iki tarafinda çocuğu yanına almak istemesi durumunda çocuğun kime teslim edileceği meselesi önemli bir sorun olarak karşımıza çıkmaktadır. Böyle bir durumda çocuğun yaş itibariyle hangi dönemde olduğu önem arz etmektedir. Çünkü özellikle çocuğun annesine ihtiyaç duyduğu süre zarfında onun yanında kalması konusunda fakihler arasında ittifak bulunmaktadır. Bu sürenin genellikle çocuğun doğduğu andan itibaren temyiz dönemine kadar olan süreci kapsadığı belirtilmiştir. Genel olarak 7-8 yaşındaki bir çocuğun temyiz dönemine ulaştığı görüşü hâkimdir (Mâverdî, 1994, C: XI, s. 499; İbn Kudâme, 1988, C:XI, s. 418; Derdîr, 1986,II, s. 755).

Bunun sebebi Hz. Peygamber'den nakledilen şu rivayettir:

"Yedi yaşına gelince çocuklarınıza namaz kılmalarını emredi$n i z ”$ (Ebû Dâvûd, Salât, 26).

$\mathrm{Bu}$ rivayetin, çocuğun tek başına yeme, içme vb. ihtiyaçlarını karşılayabildiği bir döneme işaret ettiği ifade edilmiştir. Çünkü namazın emredilmesi ancak tek başına ihtiyaçlarını karşılayabilecek ve abdest alabilecek bir çocuk için söz konusu olabilir (Kâsânî, 2005, C: V, s. 173; İbnü'l-Hümâm, 2003, C: IV, s. 334). Bu bağlamda fikıhta çocukluk dönemleri temyiz öncesi ve temyiz dönemi ile temyiz döneminden bülûğ çağına kadar olan dönem ve bülûğdan sonra rüşd dönemi kapsamında ele alınmış ve çocuğun bakım ve yetiştirilmesine yönelik hükümler belirlenirken bu dönemler esas alınmıştır.

Boşanma sonrasında çocuğun temyiz dönemine kadarki süreçte annesine teslim edilmesi konusunda ittifak bulunurken asıl 
problem annenin bulunmadığ kaybettiği durumlarda ortaya çıkmaktadır. Böyle bir durumda çocuğun kimin yanında kalacağı meselesi daha çok anne ya da baba tarafından kadın akrabalar açısından ele alınmıştır. Bu sebeple çocuğun babasına teslim edilebileceği konusu ancak bu kadın akrabaların bulunmadığı durumlarda mevzu bahis olmuştur. Burada hâkim görüş anneden sonra anneannenin, onun bulunmadığı durumlarda ise babaanne veya teyzenin çocuk üzerinde öncelikli olarak hak sahibi olması yönündedir.

Konunun bu şekilde ele alınmasında gerek annenin babaya oranla daha fazla hak sahibi olduğunu bildiren rivayetler gerekse sahabenin bu yöndeki uygulaması etkili olmuştur. Ayrıca annenin, dolayısıyla diğer kadın akrabaların, bu dönemdeki bir çocuğun bakımı ve yetiştirilmesi konusunda babaya, dolayısıyla diğer erkek akrabalara oranla fitrat olarak daha yetkin, daha şefkatli ve sabırlı olduklarına dair gerekçeler sunulmuştur. Bu gerekçeler de anneden sonra diğer kadın akrabaların, baba da dahil, erkek akrabalardan daha fazla hak sahibi olduğu şeklindeki görüşün yaygınlık kazanmasına sebep olmuştur. Ancak, Mâlikîler (Kayrevânî, 1999, C: V, s. 60; Bağdâdî, 2000, C: III, s. 1407; İbn Rüşd, “t.y.”, C: III, s. 1043) başta olmak üzere annenin bulunmadığı durumlarda babanın öncelikli olarak hak sahibi olduğu görüşünü ileri sürenler de vardir.

Mâlikîlerin dışında ise fakihler genellikle, temyiz dönemine kadarki süreçte çocuğun annesinin bulunmadığ sına teslim edilmesinin gerekliliği üzerinde durmamışlardır. Ancak farklı görüşler olmakla birlikte çocuğun yaşı, kız ve erkek oluşu göz önünde bulundurularak bazı durumlarda özellikle de temyiz döneminden sonra çocuğun babasına teslim edilmesi gerektiği düşüncesini savunmuşlardır. Bu fakihler babanın çocuk üzerindeki hakkını ifade etmek açısından görüşlerini gerekçelendirirken, aslında anne ve babanın çocuğun bakım ve yetiştirilmesi konusunda eşit haklara sahip olduğunu ifade etmişlerdir. Ancak annenin şefkat ve merhamet açısından çocuğa daha yakın olduğu için tercih edildiğini dile getirmişlerdir (Mâverdî, 1994, C:XI, s. 49; İbn Kudâme, 1988, C: XI, s. 414). 
Çocuğun bakım ve yetiştirilmesi konusunda fitrat olarak kadınların daha yetkin ve erkeklere oranla daha şefkatli olduğu görüşü isabetli kabul edilebilir. Ancak bu durum gerek anne tarafindan gerek baba tarafından bütün kadınların çocuğu annesi gibi şefkatli ve merhametli bir şekilde bakıp yetiştirebileceği sonucunu doğurmaz. Burada dikkat edilmesi gereken husus, çocuğa karşı herkesten çok şefkat ve merhamet duygularına sahip kimselerin öncelikle çocuğun anne ve babası olduğu gerçeğidir. Süt emzirme ve nafakayla ilgili sorumluluklara dair hükümlerin yer aldığ 1 Bakara sûresinin 233. âyetinde "اولادهن" (çocuklarını) ifadesi geçmektedir. Burada aidiyet bildiren "هن" zamiri çocukların annelerine izâfe edildiğini gösterir-

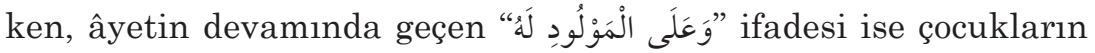
babalarına ait olduğuna işaret etmektedir. Nitekim fakihler âyetteki babalara ilişkin bu ifadeden hareketle çocukların velâyetinin babalarına ait olduğu sonucunu çıkarmışlardır. Yine aynı âyetin devaminda “وَعَلَى الْوَارِثِ مِثْلُ ذَلِكَ (mirasçı da aynı şeyle sorumludur) ifadesi bulunmaktadır. Bu ifadeyle de anne ve babanın bulunmadığı durumlarda çocuğun sorumluluğunun diğer akrabalara geçtiği açıkça belirtilmiştir.

Dolayısıyla yukarıda geçen âyetteki aidiyet bildiren zamirlerden çocuktan sorumlu olacak kişilerin öncelikle anne ve babaları olduğu ancak onların bulunmadığı durumlarda üçüncü kişilerin hak sahibi olabileceği bildirilmektedir. Nitekim Hz. Peygamber'den nakledilen ve taraf olarak anne ile babanın her ikisinin de bulunduğu örneklerde geçen ve annenin daha hak sahibi olduğunu bildiren "ehak" ifadesi de, bu durumu desteklemektedir. Çünkü bir tarafin daha fazla hak sahibi olduğundan bahsedilmesi doğal olarak diğer tarafin da hak sahibi olduğuna işaret eder; burada ise diğer taraf babadır. Dolayısıyla çocuğu yanına alma şartlarını hâiz olduğu sürece anneden sonra hak sahibi olacak kişi baba olmalıdır.

\section{Hidâne Müessesesinin Günümüz Hukuku ile Mukayesesi}

Gerek günümüz hukukunda gerekse İslâm hukukunda hâkimin takdir yetkisi olmakla birlikte şartların ve tarafların durumunun söz konusu yetki üzerinde önemli bir rolü bulunmaktadır. 
Nitekim günümüz hukukunda boşanma sonrasında çocuğun anne ya da babasından kime teslim edileceği meselesi hâkimin takdir yetkisine birakılmıştır. Bu durum, Medenî Kanunun 182/1 maddesine göre boşanma kararıyla birlikte hâkim, çocuğun teslim edileceği tarafla ilgili işlemleri de yapmalıdır şeklinde düzenlenmiştir.

Çocuk taraflardan birine teslim edilirken göz önünde bulundurulan temel ilke çocuğun menfaatinin ve güvenliğinin sağlanmasıdır. Bu sebeple hâkim çocuğun teslim edileceği tarafı belirlerken anne ve babanın sosyal ve ekonomik durumlarını, ruhsal ve bedensel açıdan sağlık durumlarını ve eğitim düzeylerini dikkate alır. Aynı şekilde çocuğun yaşını, anne babasıyla olan ilişkisini, görüş bildirecek seviyeye gelip gelmediğini, aklî ve bedenî gelişimi ile psikolojik durumunu da göz önünde bulundurup, menfaatini ön planda tutarak uygun gördüğü tarafa teslim edeceği ifade edilmiştir (Research and Statics Division, 1997, s. 9-10; Arabacı, 2008, s. 11). İslâm hukukunda çocukların menfaatinin korunması bir ilke olarak benimsendiği gibi günümüz hukukunda da velâyet düzenlenirken hâkimin "Çocuğun Yüksek Yararı İlkesi” ne göre hareket etmesinin gerekliliği üzerinde durulmuştur (Serdar, 2008, C: X, s. 182). Bu sebeple Medenî hukukta çocuğun teslim edileceği tarafın tespit edilmesi açısından tarafların sahip olması gereken bazı şartlar aranmıştır. Anne babanın hastalığı, özürlü olması ya da akıl hastası olması şeklinde sağlık sorunları çocuğa gereği gibi bakmasına engel olur. Bunların yanı sıra kişinin çocuğa bakmasını engelleyecek derecede yaşlı olması, hapiste bulunması, alkol vb. bağımlılıklar edinmiş olması ve ahlâk dışı bir yaşam tarzını benimsemiş olması da çocuğun kendisine teslim edilmesine engel olarak kabul edilmiştir (Öztürk, 2000, s. 135).

İslâm hukukunun uygulandığı Osmanlı Dönemi'nde boşanmış ailelerin çocuklarına yönelik problemlerin hidâne hükümleri çerçevesinde çözüldüğü görülmektedir. Konuyla ilgili olarak Osmanlı hukuku temelinde cereyan etmiş ve İzmir şer'iyye sicillerinde yer alan bir davada çocuğun bakım ve yetiştirilmesi sorumluluğunun anneannesine, nafakasının ise babasına verildiği ifade edilmiştir (Karakoç, 2015, s. 190). Günümüz hukukuyla İslâm hukuku arasındaki farkı göstermesi bakımından önemli bir örnek olan bu dava İslâm hukukunda dolayısıyla Osmanlı hukukunda şahsî ve malî bakım 
sorumluluğunun taraflar arasında paylaştırıldığını göstermektedir. Ancak günümüz hukukunda velâyetin taraflar arasında bölünüp bölünemeyeceği meselesi tartışma konusu olmuştur. Medenî Kanuna göre velâyet sahibi kimse, çocuğun hem şahsını hem de mallarını idare etmekle yükümlüdür (Arabacı, 2008, s. 45). Konuyla ilgili farklı görüşler olmakla birlikte TMK'nın 339. maddesinde velâyetin bölünemeyeceği ilkesi benimsenmiştir.

Fıkıhta yeniden evlilik meselesine çocuğun menfaati gözetilerek bakılmakla birlikte bu konunun özellikle anne açısından ele alındığı ve bazı fakihlerin annenin başka biriyle evlenmesinin çocuğu yanında bulundurma hakkına engel olacağı görüşüne sahip oldukları belirtilmişti. Medenî Kanunun 349. maddesine göre ise velâyet hakkına sahip olan tarafin başkasıyla evlenmesi doğrudan velâyet hakkına engel bir durum olarak görülmemiştir (Dural, Öğüz ve Gümüş, 2015, C: III, s. 355). Ancak evlenmenin çocuğun menfaatine zarar vermeye başlaması ve onu psikolojik açıdan olumsuz etkilemesi durumunda hâkim, velâyetin değiştirilmesi yönünde karar verebilir (Çelikel, 2006, s. 71). Nitekim İslâm hukukunda olduğu gibi TMK'nın 183. maddesine göre de, velâyet hakkına sahip olan anne veya babanın bu haktan doğan görev ve sorumluluklarını gereği gibi yerine getirmemesi şeklinde sonradan ortaya çıkan durumlarda, çocukların korunması amacıyla velâyetin değiştirilmesi söz konusu olabilir (Serdar, 2007, C: IX, s.777).

İslâm hukukuyla günümüz hukuku arasındaki en temel ayrım velâyetin taraflarının belirlenmesi konusundadır. İslâm hukukunda özellikle temyiz dönemine kadarki süreçte çocuklar, annelerinin herhangi bir sebeple hakkını kaybetmeleri durumunda babalarına değil üçüncü kişilere teslim edilir. Günümüz hukukunda ise anne veya babanın dışında üçüncü kişilere velâyet hakkı tanınmamıştır.

İslâm hukukunda olduğu gibi günümüz hukukunda da anne veya babanın başka bir yere taşınması konusunda çocuğun maslahatı göz önünde bulundurulmuş ve gerektiğinde velâyetin yeniden düzenlemesi konusunda hâkime yetki verilmiştir (Arabacı, 2008, s. 53). Bu ve benzeri durumların ortadan kalkması sonucunda ise velâyet hakkının sahibine tekrar verilip verilmeyeceği meselesi de günümüz hukukunda düzenlenmiştir. 
İslâm hukukunda olduğu gibi günümüz hukukunda da velâyetin anne babadan kime verileceğinin tespiti konusunda çocuğun yaşı önemli bir kıstastır. Özellikle anne bakım ve şefkatine muhtaç olan çok küçük yaştaki çocuğun velâyeti annenin bir kadın olarak çocuğun bakımı konusunda daha yetkin olduğu ve ihtiyaçlarını daha iyi karşılayabileceği düşüncesinden hareketle anneye verilir (Çelikel, 2006, s. 43-44). Yargıtay anne bakım ve şefkatine muhtaç olan çocuk için bir yaş sınırı belirlememiştir. Burada gelişim psikolojisinin verilerinden yararlanılmıştır. Gelişim psikolojisi ise çocuğun gelişim aşamalarını (1) 0-3 yaş, (2) 3-6 yaş, (3) 6-13 yaş ve (4) 13-17 yaş grubu şeklinde dört döneme ayırmaktadır (Arabacı, 2008, s. 17).

0-3 yaş grubundaki çocukların velâyeti anneye verilmekle birlikte bazı durumlarda, çocuk anne sütüne muhtaç olsa bile menfaati gereği babasına teslim edileceğine dair düzenlemeler de vardır. Örneğin, annenin hasta olması halinde çocuğuyla yeteri kadar ilgilenemeyeceği durumlar göz önünde bulundurulur. Aynı şekilde annenin çocuğunun eğitimiyle bizzat ilgilenemeyeceği ancak babanın çok yakından ilgileneceği anlaşılırsa çocuğun psikolojik, ahlâkî ve fikrî gelişimi düşünülerek küçük çocuğun velâyeti babasına verilebilir (Çelikel, 2006, s. 45). 3-6 yaş grubundaki çocukların annelerine olan ihtiyacı 0-3 yaş grubuna göre daha azdır. Ancak yine de çocuğun velâyetinin annesine verilmesi tercih edilmelidir.

Günümüz hukukundaki ilk iki dönem kapsamında olan 0-3 / 3-6 yaş grubunun İslâm hukukundaki temyiz öncesi döneme karşılık geldiği söylenebilir. Ancak İslâm hukukunda farklı görüşler olmakla birlikte temyiz dönemindeki yaş sınırı yedi olarak belirlenmiştir. Bu dönemde kız ya da erkek çocuk ayrımı yapılmaksızın çocuğun annesine teslim edilmesi konusunda ittifak vardır. Her iki hukukta da bu yaş grubundaki çocukların benzer gerekçelerle annelerine teslim edilmesi uygun görülmüştür. Tek fark günümüz hukukunda çocuğun anne sütüne muhtaç olması durumunda dahi menfaatine uygun düşmesi koşuluyla babasına teslim edilebileceği görüşüdür.

Günümüz hukukunda 6-13 yaş grubundaki çocuklar annelerine teslim edilebileceği gibi babalarına da verilebilir (Arabacı, 2008, 
s. 19). Bu yaş grubu İslâm hukukundaki temyiz döneminden bülûğ çağına kadarki süreye karşılık gelmektedir. Bu dönemdeki çocuğun konumuyla ilgili olarak fakihlerin görüşlerinde farklılıklar bulunmaktadır. Mâlikî ve Zâhirî mezhebine göre bu dönemdeki erkek çocuğun annesinin yanında kalması gerekirken, Hanefî̀ mezhebine göre babasının yanında kalması gerekir (İbn Hazm, 1970, C: XI, s. 749; Derdîr, 1986, C: II, s. 755). Bu dönemdeki kız çocuk ise Hanefî ve Zâhirî mezhebine göre annesinin yanında, Hanbelî mezhebine göre babasının yanında kalmalıdır. Çocukların annesinin yanında kalma süresini en uzun tutan Mâlikî mezhebine göre ise kızların evleninceye kadar annesinin yanında kalması gerekir (Kâsânî, 2005, C: III, s. 296; İbn Hazm, 1970, C: XI, s. 749; Derdîr, 1986, C: II, s. 755; Tûveyrecî, s. 38-39). Şâfiî mezhebinde diğerlerinden farklı olarak bu dönemdeki çocukların kız-erkek ayrımı yapılmaksızın anne babasından birini seçme hakkına sahip olduğu görüşü hâkimdir. Hanbelî mezhebinde ise sadece erkek çocuk seçim hakkına sahiptir (Mâverdî, 1994, C: XI, s. 499; Şirbînî, 1997, C: III, s. 600; İbn Kudâme, 1988, C: XI, s. 415). Günümüz hukukunda da bu dönemdeki çocuklar ayırtım gücüne (temyiz kudretine) sahip çocuklar kapsamındadır. Çocuğun kararı da göz önünde bulundurularak anne ya da babasından birine verilebileceği görüşü benimsenmiştir. Günümüz hukukunda 13-17 yaş grubu ise eğer babasının yanında kalıyorsa bu şekilde devam etmesi uygundur. Fakat genç kızlık döneminde olan bir çocuğun annesine verilmesinin doğru olacağı düşünülmektedir (Arabacı, 2008, s. 20; Fagan, 2012). Bu dönem İslâm hukukundaki bülûğdan rüşd dönemine kadarki çocuklara karşılık gelmektedir. İslâm hukukunda bu dönemdeki çocuklar konusunda görüş farklılıkları bulunmakla birlikte erkek çocuklar için ağırlıklı görüş tek başına yaşayabileceği yönündeyken kız çocuklarının genellikle tek başına bırakılması uygun görülmemiştir. Ancak her iki hukukta da bu konuda tercih edilen görüş erkek dahi olsa çocuğun tek başına bırakılmamasıdır. 


\section{Sonuç}

Boşanmış eşlerin çocukları üzerindeki hak ve sorumluluklarından bahsedilen konular fikıh kaynaklarında hidâne ve velâyet kapsamında işlenmiştir. Fakihler Hz. Peygamber'in annenin daha hak sahibi olduğunu bildiren rivayetlerinden hareketle, anne tarafının hem babadan hem de baba tarafindan öncelikli olarak hak sahibi olduğu sonucuna ulaşmışlardır. Bu görüşün arka planında anne başta olmak üzere diğer kadın akrabaların -baba da dahil diğer erkeklere oranla- hem çocuğa karşı daha şefkatli ve merhametli hem de çocuğun bakım ve yetiştirilmesi konusunda daha yetkin olduğu düşüncesi bulunmaktadır.

Çocuğun temyiz dönemine kadarki süreçte annesinin yanında kalmasının daha uygun olacağı konusunda ittifak olmakla birlikte annenin herhangi bir şekilde hakkını kaybetmesi durumunda çocuğun teslim edileceği tarafla ilgili farklı görüşler bulunmaktadır. Temyiz döneminden sonra ise çocuğun annesine mi yoksa babasına mı teslim edileceği konusu çocuğun cinsiyeti ve yaşı göz önünde bulundurularak belirlenmiştir.

Yapılan değerlendirmeler sonucunda annenin herhangi bir sebeple hakkını kaybettiği durumlarda babanın çocuğunu yanına alma konusunda üçüncü kişilerden öncelikli olarak hak sahibi olması gerektiği kanaatine ulaşılmıştır. Nitekim âyet ve hadislerden çıkarılan sonuçların yanı sıra bazı Mâlikî fakihler de, annenin bulunmadığı durumlarda babanın -çocuğu yanına alması için gerekli şartları taşıması koşuluyla- öncelikli hak sahibi olduğu görüşünü ileri sürmektedir.

Konu İslâm hukukunda daha çok hidâne ve velâyet kapsamında günümüz hukukunda ise sadece velâyet kapsamında ele alınmıştır. Ayrıca İslâm hukukunda çocuğun teslim edildiği taraflar arasında anneanne gibi üçüncü kişilerin de bulunmasına rağmen günümüz hukukunda taraflar sadece anne ve babalardır. İslâm hukukunda çocuğun belirli bir süreliğine annesine sonrasında ise babasına teslim edilmesi durumu söz konusudur. Ancak günümüz hukukunda velâyetin bölünmezliği ilkesinden hareketle velâyet sadece kendisine verildiği tarafa ait olmaktadır. 
Her iki hukukta da çocuğun menfaatinin korunması bir ilke olarak belirlenmiştir. Bu bağlamda çocuk, bazı şartları taşıması koşuluyla taraflardan birine teslim edilmiştir. Ancak İslâm hukukunda gerekli olan şartların yanı sıra sadece annenin ve sadece babanın taşıması gereken özel şartlar da belirlenmiştir. Farklı görüşler olmakla birlikte fakihlerin bir kısmına göre annenin çocuğunu yanına alabilmesi için evlenmemesi gerektiği şart koşulmuştur. Ancak gerek âyet ve hadislerden gerekse bazı fakihlerin görüşlerinden annenin evlenmesinin çocuğunu yanına almasına engel olmadığ maktır. Nitekim günümüz hukukunda da tarafların evliliği velâyet hakkına doğrudan engel olmamakla birlikte çocuğun bu evlilikten zarar görmesi halinde velâyetin değiştirilmesi söz konusu olmaktadır. Yine İslâm hukukunda velâyet, çocukluk dönemleri dikkate alınarak düzenlendiği gibi günümüz hukukunda da çocukluk dönemleri konusunda gelişim psikolojisinin verilerinden istifade edilmiştir.

\section{A Comparison of Hidanah Tradition in Islamic Law with Current Practice}

Family is the basic unit of society. Bringing up children in a peaceful environment within the family is essential. This, however, does not always happen. In today's society, we witness an increase in the number of divorced families, which brings about various problems. In cases of divorce, the question "who will hold the right and responsibility of childcare" arises. This frequently poses another problem requiring legal arrangements both about the party with whom the child stays and the other party. Mostly in divorced families, children live in a sort of orphan-hood because their right of living with both parents is taken away from them. Sometimes the inevitability of living with one of the parents negatively affects the children, both psychologically and socially. Such conditions prevent kids from being a sound part of society. These negative effects must be eliminated. In order to eliminate the negative effects caused by divorce, we must provide the best possible environment for children, and both parents - the one who the child will stay with and the other - must fulfill their duties toward the child. 
Therefore, both Islamic and Modern law established regulations which prevent the children of divorced families from being affected by those unfavorable conditions.

In Islamic Law, principally, the father has the custody of the child since birth. During marriage, both mother and father practice the right of custody. They jointly share the responsibility of caring for and meeting the needs of the child. Problems, however, arise when the spouses separate and divorce. Though the rights and responsibilities over the child are preserved jointly, they need to be shared among the parents in accordance with the new set of conditions.

In such cases, new problems arise. With whom will the child stay and for how long? Which parent holds what rights and controls over the child? And, many more. Although the default custodian is the father, shall it continue to be so even after the divorce, or does the mother also have the right to custody? After the divorce, who will be responsible for the financial, physical and emotional support of the child? Under what conditions and how long will the child be provided for? What are the criteria to determine these conditions?

These questions bring forth the concept of "hidanah" which is a subset of child custody in Islamic Law. The establishment of "hidanah" which is a notion peculiar to Islamic Law, goes back to the era of Prophet Muhammad (pbuh). The very first instances of this tradition were the solutions and answers provided by Prophet Muhammad (pbuh) in response to requests brought to him by families and questions about who should take the custody of the child in the case of divorce. In classical Islamic jurisprudence, these issues were not discussed under a distinct title but under the titles contained in the categories of divorce, sustenance/alimony and custody, which are generally considered within the concept of hidanah, which advises accommodating the child near his/her mother until a fixed age, so that the child's needs are met in the best way.

As a natural consequence of divorce, children have to stay with their mothers or fathers until a time when they can take 
care of themselves. For the best possible care for the child, the parent who is responsible for him/her has to possess certain qualifications or comply with certain conditions, most of which have been determined in law by prioritizing the well-being (maslaha) of the child. This work sheds light on the following issues: Under what conditions and for how long does the primary caregiver of the child have the right to bring up the child, and what kind of arrangements have been made in Islamic jurisprudence to be able to determine the mentioned conditions and duration. In Islamic jurisprudence, the mother is assigned the care and supervision of the child until a fixed term, about which the age range of the child plays an important role. In this respect, the childhood is divided into different age ranges: the period before discernment (tamyiz), the age of discernment (tamyiz), the period between the age of discernment (tamyiz) and puberty (bulugh), and the period between puberty (bulugh) and maturity (rushd). The rulings that apply to the care and upbringing of the child have been determined change in accordance with these periods. The age range that is most important to our study is between the ages of 0 and 7 , which is the term between birth and discernment (tamyiz), because this range is the period when children need their mothers the most. The consensus is that the child should stay with the mother until the age of discernment (tamyiz). There are, however, differing opinions about the party with whom the child should stay in the case of mother loses the right. The decision on with whom the child should stay with after the age of discernment (tamyiz) changes depending on the age and gender of the child.

In Islamic Law, while the right of custody belongs to the father, children stay with their mothers until a fixed age. In modern law of the Turkish Republic, the legal status of children in divorced families is set in the articles 182 and 183 of the civil law, where this issue is undertaken within the framework of custody. Which of the parents will be granted the custody of the child, and the arrangements regarding the personal relations of the other party with the child are matters that are left to the 
discretion of the judge presiding over the divorce case. Just as in Islamic Law, "best interests of the child" is what matters. The qualifications and conditions to which parties must adhere have been prescribed, while the age of the child is also a very important determinant.

There are prominent differences between "hidanah" in Islamic law and the regulations about child custody in Modern Law. The fundamental difference between them is about the parties that are entitled to custody. In Islamic Law, especially during the period before tamyiz, the custody over the children may be granted to third parties if the mother loses her right. In modern law, however, no one apart from the mother or the father is entitled to the custody of the child.

In this work, we will first discuss the definition, content, and scope of the notion of "hidanah" in Islamic Law briefly and then analyze the regulations on child custody in cases of divorce in Modern Law. Thereafter, we will present the differences between two bodies of laws.

\section{Kaynakça / References}

Abdulhay, Ahmed. (“t.y.”) Ahkâmu'l Hidâne fi'lFıhi'l İslâmi ve Dirasetü’l Mukârene, "y.y".

Aksakal, Sultan. (2003). "Boşanmadan Sonra Çocuğun Velâyeti”, KSÜ İlahiyat Fakültesi Dergisi, Sayı, 1, s. 167-190.

Âmir, Abdülazîz Musa. (“t.y.”) el-Ahvâlü'ş-şahsiyyefi's-şeriati'l-İslâmiyye flkhen ve kazaen: neseb, hadâne, nefakatül-ekârib, Kahire: Dârü'l-Fikri'l-Arabi.

Arabacı, Gülistan Pişken. (2008). "Boşanmanın Çocuklar Bakımından Sonuçları", Yayımlanmamış Yüksek Lisans Tezi, Konya.

Bağdâdî, Ebû Muhammed Abdülvehhab b. Ali b. Nasr. (2000). Uyûnü'lmecâlis, thk. Ambay b. Keybakah, 5 c., Riyad, Mektebetü'r-Rüşd.

Bardakoğlu, Ali. "Vesâyet", DİA, C: XXXXIII, s. 66.

Ali. "Hidâne”, DIA, C: XVII, s. 467.

Cevherî, Ebû Nasr İsmail b. Hammâd. (1990). Sihâhfi’l-lüğa, thk. Ahmed Abdulgafur Attâr, 6 c., 4. bs., Beyrut, Dâru'l-İlmli'l-Melâyîn.

Cürcânî, Seyyid Şerîf. Kitabu't-Ta'rifât.(1983). Beyrut, Dârü'l-Kütübü'l İlmiyye. 
Çelikel, Serdar. (2006). "Boşanmanın Çocuklara İlişkin Hukuki Sonuçları", Yayımlanmamış Yüksek Lisans Tezi, Kırıkkale.

Çolak, Abdullah. (2017). İslam Aile Hukuku, 3. bs, Ankara, Öncü Basım Yayın.

Derdîr, Ebu'l-Berekât Sîdî Ahmed b. Muhammed. (1986). eş-Şerhu's-sağîr alâ Akrabi'l-mesâlik ilâ mezhebi'l-İmâm Mâlik, nşr. Mustafa Kemal Vasfî, 4 c., Kahire, Dâru'l Meârif.

Desûkî, Muhammed b. Ahmed b. Arafe. (2003). Hâş̧iyetü'd-Desûkî ale'şŞerhi'l kebîr, 6 c., 2 bs. Beyrut, Dâru'l Kütübü'l İlmiyye.

Dural, Mustafa, Öğüz Tufan, Gümüş, Mustafa Alper. (2015). Türk Özel Hukuku (Aile Hukuku),10 bs., İstanbul: Filiz Kitabevi.

en-Nesâî, Muhammed Nâsıriddîn el-Elbânî. (1998). Sahîhu Süneni’n-Nesâ̂î, 3 c., Riyad, Mektebetü'l-Mârife li-Neşrîve't-Tevzî‘.

Ensarî, Ebu Yahya Zeynüddin Zekeriyya b. Muhammed. (2001). Esne’lmetâlib şerhu Ravdı't-tâlib, 9 c., thk. Muhammed Tamer, Beyrut, Dâru'l Kütübü'l İlmiyye.

Erbay, Celal. (1998). İslam Hukukunda Küçüklerin Himayesi, 2. bs, İstanbul, Rağbet Yay.

Erdoğan, Mehmet. (2010). Fıkıh ve Hukuk Terimleri Sözlüğü, 3. bs., İstanbul, Ensar Neşriyat.

Ergüney, Hilmi. (1973). Türk Hukukunda Lügat ve Istılahlar, İstanbul, Yenilik Basımevi.

Ebû Dâvûd, Süleyman b. Eş'as b. İshak el-Ezdi es-Sicistani. (1998). Sünenu Ebû Dâvud, thk. Muhammed Avvame, Cidde, 4 c., Dârü'l-Kıble li’sSekâfeti İslâmiyye.

Ezherî, Ebû Mansur Muhammed b. Ahmed b. Ezherel-Herevi. "t.y.” Tehzibü'l-luga, thk. Abdülkerim el-Garbavi, 15 c., Kahire, ed-Dârü'l-Mısriyye li't-Te'lifve't-Terceme.

Fagan, Patrick F., Churchill, Aaoran. ( 2012). "The Effect of Divorce On Children", Marri Research Synthesis, Washington: s. 1-48.

Feyyumî, Ebü'l-Abbas Ahmed b. Muhammed b. Ali el-Hamevi. "t.y.”, elMisbahü’l-münir, Mustafa el-Bâbî el-Halebî ve evlâduhû , 2 c., Mısır, Dârü'l-Kütübü'lArabiyyeti'l Kübra.

Fîrûzâbâdî, Ebu't-Tahir Mecdüddin Muhammed b. Yakub. (1987). elKâmûsü'l-Muhît, 14 c., Dımeşk, Müessesetü'n-Nûrî.

İbn Âbidîn, Muhammed Emin b. Ömer İbn Âbidîn. (2000). Hâşiye Reddülmuhtârale'd-Dürri'l-muhtâr, kısmü'l-ahvâli'ş-şahsiyye: talak, thk. Hüsameddin b. Muhammed Salih Ferfur, 10 c., Dımaşk, Ma'hedu Cemiyyetü'l-Fethi'l-İslâmî, Dârü's-Sekâfeve't-Türâs.

İbn Fâris, Ebu'l-Hüseyn Ahmed. (1980). Mu'cemü'l-mekâŷ̂'îl-lüğa, thk. Abdüsselam Muhammed Harun, 6 c., 3. bs., Kahire. 
İbn Hanbel, Ebû Abdullah Ahmed b. Muhammed eş-Şeybânî. (2001). Mevsûatü'l-hadîsiyye (Müsnedü el-İmam Ahmed b. Hanbel), thk., Şuayb el-Arnaût vd., 50 c., Beyrut, Müessesetür-Risâl.

İbn Hazm, Ebu Muhammed Ali b. Ahmed. (1970). el-Muhallâbi'l-âsâr, thk. Ahmed Muhammed Şakir, 11 c., Kahire, Mektebetü'l Cumhuriyyetü'l Arabiyye.

İbn Mâce, Ebû Abdullah Muhammed b. Yezid er-Rebei el-Kazvini. (1996). Sünenü İbn Mâce, thk. Halil Me'mun Şiha, 4 c., Beyrut, Dârü'l-Ma'rife.

İbn Manzûr, Ebu'l-Fadl Muhammed b. Mükerrem b. Ali el-Ensârî. (2008). Lisânü'l-Arab, Beyrut, 16 c, 6. bs., Dâru Sadır.

İbnü'l-Arabî, Ebu Bekir Muhammed b. Abdullah. "t.y.”, Ahkâmu'l-Kur'ân, thk. Muhammed Abdülkadir Atâ', 4 c., Beyrut, Dâru'l Kütübü'l İlmiyye.

İsfahânî, Râgib. (2009). Müfredât, thk. Safvan Adnan Dâvûdî, 4. bs., Beyrut, Dâru'ş-Şâmiyye.

İbn Kudâme, Ebû Muhammed Muvaffakuddîn Abdullah b. Ahmed b. Muhammed Makdisî. (1997). el-Muğnî, 5 c., 3.bs., Riyad.

İbn Nüceym, Zeynüddin b. İbrâhim el-Misrî. (1997). el-Bahru'r-râik şerhu Kenzi'd-dekâik, 9 c., Beyrut.

İbn Rüşd, Ebü'l-Velid Muhammed b. Ahmed b. Muhammed Kurtubi. "t.y.” Bidâyetü'l-müctehid ve nihâyetü'l-muktesıd, 4 c., Dâru İbn Hazm.

İbnü'l-Hümâm, Kemalüddîn Muhammed b. Abdulvâhid. (2003). Fethu'lKadîr, 10 c., Beyrut: Dâru'l Kütübü'l İlmiyye.

Karakoç, İrem: "Bir İslam Hukuku Müessesesi Olan Hidâne Hakkının ve Osmanlı Aile Hukukunda Uygulanışının İzmir Şer’iyye Sicillerinde Yer Alan Bir Karar Örneği Üzerinden İncelenmesi”, Gazi Üniversitesi Hukuk Fakültesi Dergisi, C: XIX, s. 151-206.

Karaman, Hayrettin. (2005). Ana Hatlarıyla İslam Hukuku,3 c., 11. bs, İstanbul, Ensar Neşriyat.

Kâsânî, Ebû Bekr b. Mes'ûd. (2005). Bedâi'u's-Sanâi' fî tertîbi'ş-şerâi', thk. Ali Muhammed Muavviz, Adil Ahmed Abdülmevcut: 10 c., Beyrut: Dârü'l-Kütübi'l-İlmiyye.

Kayrevânî, Ebû Muhammed Abdullah b. Abdurrahman İbn Ebû Zeyd. (1999). en-Nevâdirve'z-ziyâdat alâ mafîll-müdevvene ve gayriha mine'l-ümmehât, thk. Muhammed Abdülazîzed-Debbağ, 5 c., Beyrut, Dârü'l-Garbi'l-İ̀slâmî.

Mâverdî, Ebu'l-Hasan Ali b. Muhammed b. Habîb. (1994). el-Hâvi'l-Kebîr hüve Şerhu Muhtasaru'l-Müzen̂े, thk. Ali Muhammed Muavvız ve Adil Ahmed Abdülmevcûd, 19 c., Beyrut, Dârü'l-Kütübi'l-İlmiyye.

Oğuzman, Kemal ve Dural, Mustafa. (1998). Aile Hukuku, 2. bs, İstanbul: Filiz Kitabevi.

Özen, Şükrü. "Velâyet", DİA, C: XXXXIII, s. 16. 
Öztürk, Huriye Reyhan. (2000). Türk Medeni Hukukunda Velâyet ve Bunun Çocuğun Şahsı Bakımından Sonuçları, Yayımlanmamış Yüksek Lisans Tezi, Ankara.

Researchand Statics Division. (1997). "The Effect of Divorce On Children, A Selected Literatüre Review", Working Document Department of Justice Ministre de la Justice, Canada: s. 1-28.

Serahsî, Ebû Bekr Şemsüleimme Muhammed b. Ahmed b. Sehl. (h.1324). el-Mebsut, 30 c., Kahire: Matbaatü's-Saade.

Serdar, İlknur. (2007). "Kişisel İlişki Kurma Hakkı”, Dokuz Eylül Üniversitesi Hukuk Fakültesi Dergisi, C: 9, Özel Sayı, s. 739-781.

Serdar, İlknur. (2008). "Birlikte Velâyet”, Dokuz Eylül Üniversitesi Hukuk Fakültesi Dergisi, C: X, Sayı, I, s. 155-197.

Şa'ban, Zekiyyüddin. (1989). el-Ahkâmü'ş-şer'iyyeli'l-ahvâli'ş-şahsiyye, 5. bs., Bingâzi, Câmiatu Karyûnus.

Şirbînî, Şemsüddîn Muhammed b. Muhammed el-Hatîb. (1997). Muğni’lmuhtâc ilâ ma'rifetimeânîelfâzi'l-Minhâc, nşr. Muhammed Halil Aytânî, 5 c., Beyrut, Dâru'l Mârife.

Tantavî, Mahmûd Muhammed. (1979). el-Ahkâmü's-şer'iyyefi'ş-şerîati’l islâmiyye, s. 406.

Tirmizi, Ebû İsa Muhammed b. İsa b. Sevre es-Sülemi. (1998). Sünenü’tTirmizi, thk. Beşşar Avvad Ma'ruf, 4 c., Beyrut, Dârü'l-Garbi'l-İslâmî.

Yazır, Elmalılı M. Hamdi. (1997). Alfabetik İslam Hukuku ve Fıkıh Istılâhları Kâmusu, İstanbul, Eser Neşriyat.

Zebîdî, Ebü'l-Feyz Murtaza Muhammed b. Muhammed b. Muhammed. (1994).Tâcü'l arûs min cevâhiri'l-Kâmûs, thk. Ali eş-Şirî, 20 c., Beyrut, Dârül-Fikr.

Zekî Süleyman, Neşvân . (2013). "el- Hidânetü ve Şurûtu Mümâresetuha”, Mecelletü’l-Râfidîneli’l Hukuk̂,, C: XVI, s. 59-99. 